\section{Christmas Lectures for Schoolboys in Chemical Engineering}

The Institute of Chemical Enginoors has organized two Christmas lectures for schoolboys which will be hold at the Lecture Theatre of the Science Museum, South Kensington, London, S.W.7, on the afternoon of January 11. Mr. E. S. Sellars, head of the Petroleum Division of the B.P. Research Centre at Sunbury, and a vico-president of the Institution of Chemical Engineers, will speak on "Stages in the Development of the Industrial Procoss", and Prof. M. W. Thring, professor of fuel technology and chemical engineoring in the University of Sheffield, will speak on "Some Possible Future Devolopments in Industry". Further information can be obtained from the Genoral Secretary, the Institution of Chemical Engineers, 16 Belgrave Square, London, S.W.1.

\section{The Australian Mathematical Society}

THE Australian Mathematical Socioty mot in Sydney, at the University of Sydney, during August 15-17; eighty members attended. The new Council elected was as follows: President, Prof. E. S. Barnes; Vice-presidents, Profs. T. G. Room and A. L. Blakers; Publications Secretary, Dr. G. E. Wall; Treasurer, Prof. C. S. Davis; General Secretary, Prof. H. O. Lancaster; Councillors for the second term, Prof. A. Brown, Prof. R. C. T. Smith and Dr. G. Szokeres; Councillors for the first term, Prof. L. S. Goddard, Dr. C. F. Moppert and Prof. K. C. Westfold. A surnmer research institute was held at the Australian National University, Canberra, during January and February, 1962, with Prof. E. S. Barnes as director. A third meeting of the institute will bo held in Canborra during January 1963, with Prof, B. H. Neumann as director. The seventh general meeting of the Society will be held at Monash University during May 21-23, 1963. Further information concerning the general meeting can be obtained from the local secretary, G. C. Smith, Dopartment of Mathematics, Monash University, Clayton, Victoria.

\section{The Welsh Solls Discussion Group}

THE following have been elected officers for the fifth session, 1962-63, of the Welsh Soils Discussion Group: Chairman, Dr. R. Williams, regional advisory chemist, National Agricultural Advisory Sorvice, Trawscoed, Cardiganshire; Secretary, J. A. Taylor, lecturer in geography, University College of Wales, Aberystwyth; Assistant Secretary, Dr. C. B. Crampton, soil surveyor, National Agricultural Advisory Service, Cardiff; Editor, D. F. Ball, Naturo Conservancy, Bangor. J. R. Hampson, Forestry Com. mission, North Wales Conservancy, Shrewsbury, was elected an ordinary member. The theme for the fifth session will be "Soil Moisture". A meoting of the Group will be held at Bangor on February 27, whon the subject will be "The Biological Role of Soil Water". Further information can be obtained from Mr. J. A. Taylor.

\section{The Night Sky in January}

Futu moon occurs on Jan. 9d. 23h. 09m. U.T. and new moon on Jan. $25 \mathrm{~d}$. 13h. $42 \mathrm{~m}$. The following conjunctions with the Moon take place: Jan. 12d. 15h., Mars $2^{\circ}$ N.; Jan. 21d. 18h., Vonus $0^{\circ} 1^{\circ}$ S.; Jan. $28 d$. 07h., Jupiter $3^{\circ} \mathrm{N}$. In addition to these conjunctions with the Moon, Venus is in conjunction with Antares on Jan. 15d, 09h., Vonus being $9^{\circ} \mathrm{N}$, There will be a ponumbral eclipse of the Moon on January 8 , visible at Greenwich; Moon onters penumbra on Jan. 9 d. $21 \mathrm{~h} .04 \mathrm{~m}$., mid-eclipse is at $23 \mathrm{~h} .19 \mathrm{~m}$. and Moon leaves penumbra at Jan. 10d. 01h. 34m. There will be an annular eclipse of the Sun on January 25, invisible at Greenwich. Mercury is an evening star visible during the first part of the month low in the south-west after sunset. Venus is a morning star, rising at $4 \mathrm{~h} .15 \mathrm{~m} ., 4 \mathrm{~h} .25 \mathrm{~m}$. and $4 \mathrm{~h} .45 \mathrm{~m}$. on Jan. 1 , 15 and 31 , rospectively. Its stellor magnitude is -4.2 ; its distance increases during the month from 47 to 69 million miles, and the visible portion of the apparent disk increases from 0.365 to 0.545 . Mars rises at $19 \mathrm{~h} .40 \mathrm{~m} ., 18 \mathrm{~h} .30 \mathrm{~m}$. and $16 \mathrm{~h}$. $55 \mathrm{~m}$. on Jan. 1,15 and 31 , respectively. It is at a distance of 66 million miles on January 15, when its stollar magnitude is $-0 \cdot 7$; conditions aro now favourable for observation. Mars is in Leo, not far from Regulus. Jupiter is an evening star, sotting at $21 \mathrm{~h} .15 \mathrm{~m} ., 20 \mathrm{~h}$. $35 \mathrm{~m}$, and $19 \mathrm{~h} .50 \mathrm{~m}$. at the beginning, middle and end of the month. It is in Aquarius, its stellar magnitude is -1.7 and its distance from tho Earth in the middle of the month is 520 million miles. Saturn is too close to the Sun for easy observation. Occultations of stars brighter than magnitude 6 are as follows, observations being made at Greenwich: Jan. 4d. 19h. 04.5m., $\xi^{2}$ Cet. $(D)$; Jan. 6d. $20 \mathrm{~h}$. $30.7 \mathrm{~m} ., 63 \mathrm{Tau} .(D)$. $D$ refers to disappoarance. The Quadrantid meteors are active on January 3 , the radiant being near R.A. $15 \mathrm{~h} .28 \mathrm{~m}$., Dec. $+50^{\circ}$. The Earth is at porihelion on January 4, its distance from the Sun being 91.4 million miles.

\section{Announcements}

Mr. H. FAULKNER, director of the Telecommunication Engineering and Manufacturing Association, retires at the ond of the year. Ho was formerly deputy engineer-in-chief of the British Post Office and has held office in the Association for nine yoars. Mr. Faulkner will be succeeded by Mr. R. A. Moir, until recently a director of Standard Telophones and Cablos, Ltd.

THE British Biophysical Society is organizing a meeting on "Nucleic Acids and Nucleoproteins" at King's College, Newcastle upon Tyne, during April 2-4. The titles of the symposia will be "Structure and Physicochemical Properties" and "Effects of Radiation". Further information can be obtained from the local secretary, Dr. G. Scholes, Chemistry Department, King's College, Newcastle upon Tyne 1.

THE centenary meeting of the British Pharmaceutical Conference will be hold in London during September 2-6, 1963. The closing date for the roceipt of papers to be deliverod at the meeting is May 1. The Conference Lecture is to be given by Dr. J. M. Barnes, head of the Toxicology Research Unit of the Medical Research Council. Further information can be obtained from the honorary local secretary, Dr. K. R. Cappor, 17 Bloomsbury Squaro, London, W.C.1.

The British Ecological Socioty, which was founded in 1913, will celebrate its fiftieth jubiloo with a special meoting, to be held at Queen Elizabeth Collogo, Campden Hill Road, London, W.8, during March 8-31. The meeting will include half-day sessions on various topics, ranging from "The History of Ecology in Britain" and "Quaternary Ecology" to "Production Ecology" and "Consorvation and Ecology". Further information can be obtained from P. J, Newbould, Botany Department, University College, Gower Street, London, W.C.1. 